\title{
RADIOIMMUNOASSAY FOR ANTIBODIES TO RUBELLA VIRUS AND ITS RIBONUCLEOPROTEIN COMPONENT
}

\author{
Linda Ho-Terry and A. Cohen \\ Department of Bacteriology, University College Hospital Medical School, \\ University Street, London WC1E 6JJ
}

IN PREGNANCY, the serological differentiation of recent from remote rubella infection is important, and affects the management of the patient. Currently, this depends on the interpretation of serological responses of the IgM and IgG immunoglobulin classes to the surface antigens of rubella virus, (Best, Banatvala and Watson, 1969). By analogy with influenza, in which recent infection is characterised by an antibody response to the internal ribonucleoprotein component of the virus (Francis and Maassab, 1965), the detection of antibodies to the ribonucleoprotein component of rubella virus might provide additional evidence of recent rubella infection. We have therefore investigated the antibody response to the ribonucleoprotein and envelope components of rubella virus by a radioimmune precipitation technique.

\section{MATERIALS AND METHODS}

Cells. BHK-21 cells, clone 13, were obtained from Flow Laboratories, Irvine, Scotland.

Rubella virus was kindly supplied by Professor J. A. Dudgeon, Institute of Child Health, London.

Culture media. Growth medium: minimum essential medium (Glasgow modification) was supplemented with $10 \%$ tryptose phosphate broth, $10 \%$ foetal calf serum, penicillin $100 \mathrm{IU} / \mathrm{ml}$ and streptomycin $100 \mu \mathrm{g} / \mathrm{ml}$; maintenance medium was the same as growth medium except that $4 \%$ foetal calf serum previously inactivated at $56^{\circ} \mathrm{C}$ for $30 \mathrm{~min}$. and double the concentration of sodium bicarbonate were used.

Radioactive isotopes. $\quad \mathrm{L}-\left(5-{ }^{3} \mathrm{H}\right)$ arginine monohydrochloride $(8 \cdot 8 \mathrm{Ci} / \mathrm{mmol})$ and $\left(\mathrm{U}_{-}{ }^{14} \mathrm{C}\right)$ uridine $(481 \mathrm{mCi} / \mathrm{mmol})$ were obtained from the Radiochemical Centre, Amersham, Bucks.

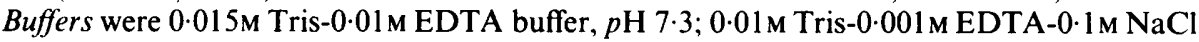
buffer, $p \mathrm{H} 7 \cdot 1$; phosphate-buffered saline (PBS), $p \mathrm{H} 7 \cdot 3$.

Serum samples were all obtained from the Department of Microbiology, University College Hospital, London. They were inactivated at $56^{\circ} \mathrm{C}$ for $30 \mathrm{~min}$. before use.

Sheep anti-human $\operatorname{IgM}, \operatorname{Ig} G$ and $\operatorname{Ig} A$ were obtained from Wellcome Laboratories, Kent.

Preparation of radioactively labelled rubella virus. BHK-21 cells were infected with rubella virus at a multiplicity of infection of 10 plaque-forming units per cell and labelled with ${ }^{3} \mathrm{H}$-arginine $(4 \mu \mathrm{Ci} / \mathrm{ml}) 24 \mathrm{~h}$ later; $72 \mathrm{~h}$ after infection, the medium was harvested and the virus concentrated by centrifugation at $50000 \mathrm{~g}$ for $2 \mathrm{~h}$ at $4 . \mathrm{C}$. The pellet was resuspended in $0.01 \mathrm{~m}$ Tris EDTA buffer at $p \mathrm{H} 7.3$ and the virus was purified by centrifugation in a linear $5-45 \%$ sucrose gradient at $200000 \mathrm{~g}$ for $2 \mathrm{~h}$ at $4 \mathrm{C}$. Six-drop fractions were collected and dialysed against PBS at $4 \mathrm{C}$ overnight before being tested for virus by haemagglutinating activity and radioactivity. The most active fractions were pooled and provided the rubella virus antigen for use in the tests.

Received 15 Jan. 1979; accepted 19 Feb. 1979.

J. MED. MICROBIO.-- VOL. 12 (1979) 
Separation of internal ribonucleoprotein component. Rubella virus labelled with ${ }^{3} \mathrm{H}$-arginine $(4 \mu \mathrm{Ci} / \mathrm{ml})$ and with ${ }^{14} \mathrm{C}$-uridine $(1 \mu \mathrm{Ci} / \mathrm{ml})$ was degraded with $1 \%$ Triton $\mathrm{X}-100$ for $60 \mathrm{~min}$. at $4^{\circ} \mathrm{C}$ in the presence of a ribonuclease inhibitor, diethyl-pyrocarbonate. The subviral components were then separated on a $15-35 \%$ linear sucrose gradient, centrifuged at $200000 \mathrm{~g}$ for $1 \mathrm{~h}$ at $4^{\circ} \mathrm{C}$. Six-drop fractions were collected, dialysed against PBS overnight at $4^{\circ} \mathrm{C}$ and their haemagglutinating activity and radioactivity were measured.

Radioimmune-precipitation test. Serum samples, inactivated at $56^{\circ} \mathrm{C}$ for $30 \mathrm{~min}$., were diluted in PBS or PBS containing $10 \%$ pooled human serum with a rubella haemagglutinationinhibiting antibody titre of $<8$. From each serum dilution, $0.1 \mathrm{ml}$ was mixed with $0.1 \mathrm{ml}$ of labelled rubella-virus antigen and held overnight at $4^{\circ} \mathrm{C}$. Next day an equal volume of sheep anti-human IgM, IgG or IgA serum, suitably diluted to give optimal precipitation (Horwitz and Scharff, 1969), was added and the mixture was held for another $24 \mathrm{~h}$ at $4^{\circ} \mathrm{C}$. Radioactively labelled rubella antigen-rubella specific human immunoglobulin-sheep anti-human immunoglobulin complexes collected by centrifugation at $1000 \mathrm{~g}$ for $15 \mathrm{~min}$. at $4^{\circ} \mathrm{C}$ were washed twice with $10 \mathrm{ml}$ of cold PBS followed by $10 \mathrm{ml}$ of cold $5 \%$ trichloroacetic acid and collected on glass-fibre filters, which were then washed three times in cold $5 \%$ trichloroacetic acid before radioactivity was counted for $10 \mathrm{~min}$. in a liquid scintillation counter (Intertechnique ABAC SL 40). Five replicate titrations of a control serum - having a rubella haemagglutination-inhibition titre of $<8$-were included in each assay.

The highest dilution of a test serum in which the mean radioactivity recovered from the precipitate differed from that of the control serum by four or more standard deviations was taken as the end point of the titration.

Separation of immunoglobulins was as described by Cradock-Watson, Bourne and Vandervelde (1972).

Haemagglutination inhibition titration was as described by Plotkin (1968).

Polyacrylamide-gel electrophoresis was as described by Terry (1977).

\section{RESULTS}

\section{Separation of internal ribonucleoprotein component}

Fig. 1 shows two subviral components, a faster sedimenting peak I labelled with ${ }^{3} \mathrm{H}$-arginine and ${ }^{14} \mathrm{C}$-uridine but with no haemagglutinating activity and a more slowly sedimenting peak II labelled with ${ }^{3} \mathrm{H}$-arginine and only a trace of ${ }^{14} \mathrm{C}$-uridine but with haemagglutinating activity. From this we conclude that peak I is the ribonucleoprotein component and its analysis by polyacrylamidegel electrophoresis showed a single polypeptide of molecular weight 32000 free from contamination with envelope-component polypeptides (fig. 2).

\section{Immunoglobulin assay with rubella virus}

The presence of rubella-specific immunoglobulins in the sera from patients with recent or remote infection was determined by the double-antibody radioimmune-precipitation test. Four serum speciments from three patients with recent clinically diagnosed rubella known to contain rubella-specific IgM antibodies and two serum specimens from patients for routine antenatal screening known to contain IgG but not IgM antibodies (remote infection), detected by conventional separation and haemagglutination inhibition techniques, were titrated in duplicate for antibodies in the IgM, IgA and IgG immunoglobulin classes by the radioimmune-precipitation technique. Representative titrations of an early serum specimen drawn 22 days after the 


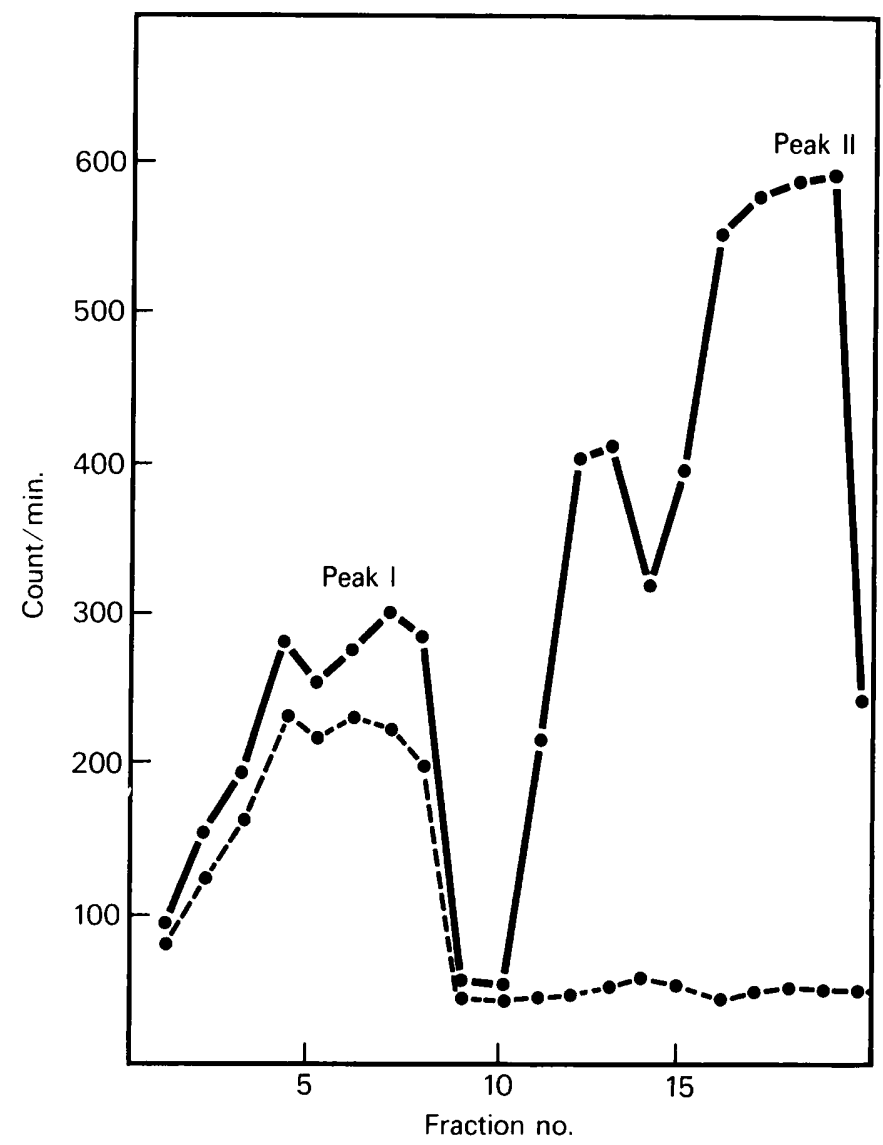

FIG. 1.- Separation of ribonucleoprotein and envelope components of rubella virus by rate zonal centrifugation in sucrose. Direction of centrifugation was from right to left. $\bullet-\bullet={ }^{3} \mathrm{H}$-arginine label, $\bullet---\bullet={ }^{14} \mathrm{C}$-uridine label.

appearance of a rubelliform rash, a routine antenatal serum specimen and a control serum specimen are illustrated in fig. 3 . The radioactivity counts per minute recovered in the precipitates obtained with serial dilutions of the control serum represents the mean of five replicate determinations from which the standard deviation was calculated. The radioactivity recovered in the precipitates obtained with serial dilutions of test sera represents the mean of duplicate determinations.

Rubella-specific IgM, IgA and IgG immunoglobulins were identified in early sera of all three patients with recent infection whereas only IgA and IgG were identified in the two late sera from patients with remote infection (table I).

\section{Immunoglobulin assay with ribonucleoprotein component}

The sera used in the above titrations were also titrated in duplicate for IgM, IgA and IgG antibodies to the ribonucleoprotein component of rubella virus. 


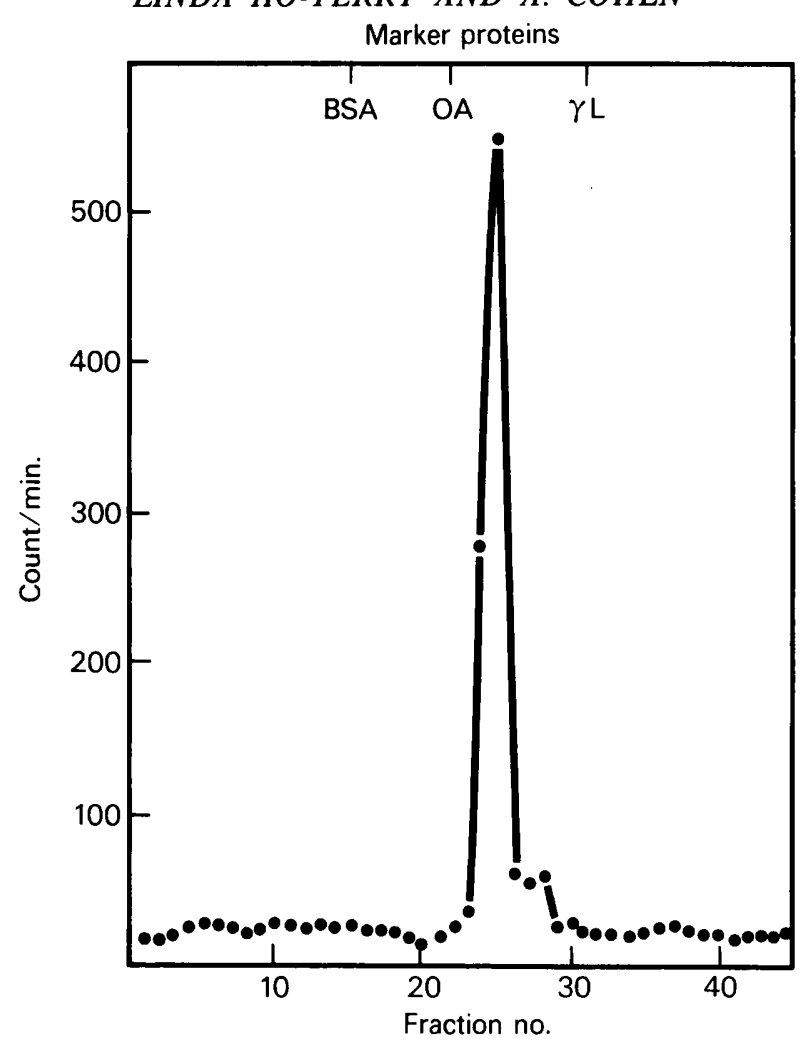

FIG. 2.-Disc electrophoresis of ribonucleoprotein component of rubella virus in $10 \%$ polyacrylamide gel. Direction of electrophoresis was from left to right. The three marker proteins were bovine serum albumin (BSA) m.w. 67000 , ovalbumin (OA) m.w. 43000 and light chain of $\gamma$-globulin $(\gamma \mathrm{L}) \mathrm{m}$.w. 25000 .

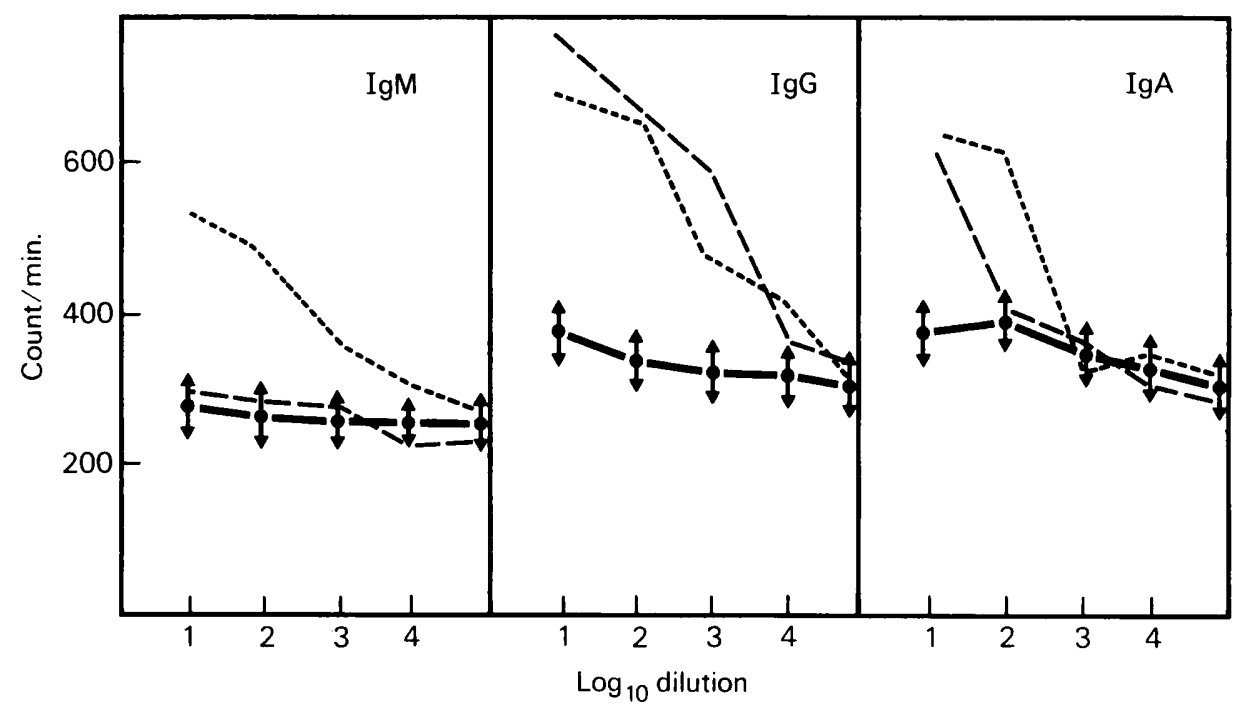

FIG. 3.-Radioimmune precipitation of ${ }^{3} \mathrm{H}$-arginine-labelled rubella virus. $\ldots$ - . - - serum from patient 22 days after rubelliform rash, $-----=$ routine ante natal serum, $\bullet \bullet=$ control serum, $\downarrow=$ standard deviation. 


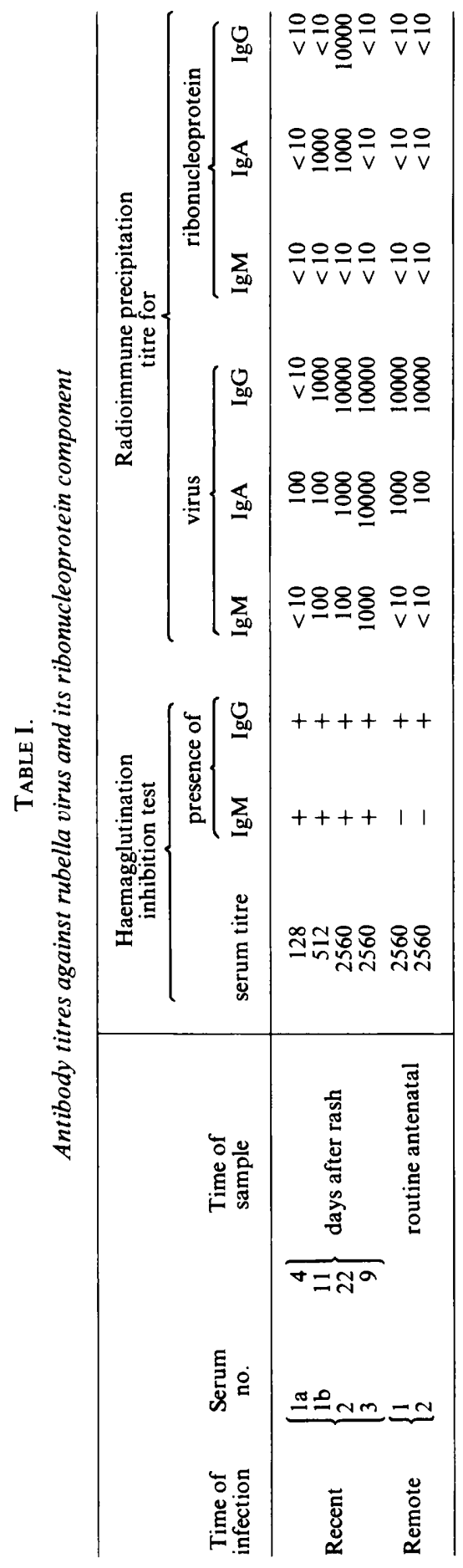




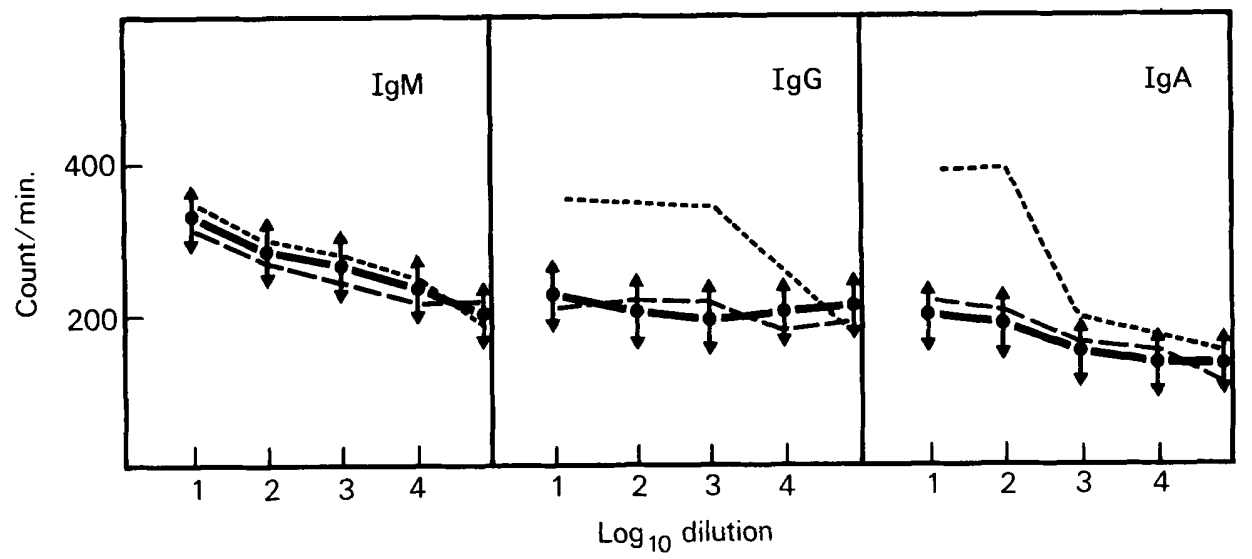

FIG. 4.-Radioimmune precipitation of ${ }^{3} \mathrm{H}$-arginine-labelled rubella ribonucleoprotein component. $\ldots . .=$ serum from a patient 22 days after rubelliform rash, $\ldots \ldots-\ldots$ routine ante-natal serum, $\bullet=$ control serum, $\mathfrak{\ddagger}=$ standard deviation.

The amount of radioactively labelled internal component precipitated by immunoglobulin of the representative sera used in fig. 3 are shown in fig. 4 . From table I it can be seen that two of the three patients with recent infection developed antibody to the ribonucleoprotein component. Surprisingly, antibody to the ribonucleoprotein component was not found in the IgM immunoglobulin, but IgA and IgG antibodies were produced. To confirm that antibodies to the ribonucleoprotein component were confined to sera from patients with recent infection, ten more sera from patients for routine antenatal screening were screened at a dilution of 1 in 10 for antibody against the ribonucleoprotein component and these results, included in table II, show that none contained any IgA or IgG antibody against the ribonucleoprotein component.

TABLE II

Antibody titres of late sera against rubella ribonucleoprotein

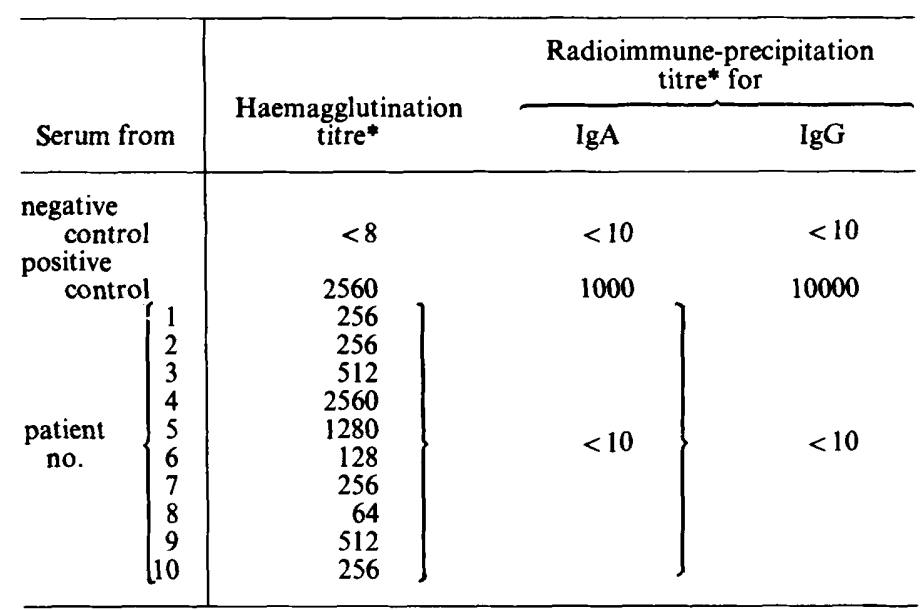

* Each titre is the mean from two experiments. 


\section{Discussion}

In this investigation, a radioimmune-precipitation method was used to measure antibodies against intact virus and its ribonucleoprotein component. The method is highly sensitive and reproducible, and does not require preliminary serum fractionation for the identification of antibodies of different immunoglobulin classes. Moreover, because it does not depend on haemagglutination or complement fixation, the antibody to another specifically labelled virus antigen - the ribonucleoprotein component, not so far detected-may be identified. To ensure maximum sensitivity, rubella-virus antigens of high specific activity and free from host contaminants are required; although this can be achieved by preparation of radioactively labelled intact virus, present techniques do not allow a good yield of radioactively labelled ribonucleoprotein component so that the detection of antibody to this antigen by the technique described here cannot yet be a routine test. The number of sera tested is small, but our results show that antibodies belonging to all three immunoglobulin classes are formed against rubella virus during infection; the IgA and IgG antibodies persist after the initial infection and are found in sera taken from patients at intervals long after infection. In this respect, our results are similar to those of Ogra et al. (1971) who detected IgA antibody by radioimmune diffusion for at least a year after rubella infection and do not agree with those of Bürgin-Wolff, Hernandez and Just (1971) and CradockWatson et al. (1972) whose methods showed that IgA antibody persisted only as long as $\operatorname{IgM}$. The presence of $\operatorname{IgA}$ antibody is not therefore an indicator of recent rubella infection. In contrast, IgA and IgG antibodies against the ribonucleoprotein component of rubella virus are detected only in sera of patients after recent rubella; and their absence from sera of patients who were remotely infected suggests that their presence is an indicator of recent rubella infection. It is of interest that one of the early sera (no. 1a) was shown to contain IgM by the conventional separation and haemagglutination-inhibition techniques but only IgA by the radioimmune precipitation test. This discrepancy suggests that sedimentation characteristics alone are not sufficient to exclude the presence of aggregates of rubella specific IgA or IgG, or non-specific inhibitors (Al-Nakib, Best and Banatvala 1974) in fractions containing IgM. Although only a few sera have been investigated for antibody to the virus ribonucleoprotein component, the results indicate that the antibody response to the ribonucleoprotein component is related to recent and not to remote infection. A test for this antibody would be a valuable addition to the laboratory tests used for the accurate diagnosis of recent rubella infection. The difficulties of preparing radioactively labelled ribonucleoprotein component prevent the use of such a test for any large-scale investigation at present, but more efficient methods of preparation are being investigated.

\section{SUMMARY}

IgA and IgG antibodies to the ribonucleoprotein component of rubella 
virus have been demonstrated by radioimmune precipitation in sera from patients with recent but not remote rubella infection. This observation suggests that a test for antibodies to the ribonucleoprotein component may provide additional evidence in the diagnosis of recent rubella infection.

We wish to thank Mr Barry Mellars for the rubella antisera and the Peel Medical Research Trust for financial support.

\section{REFERENCES}

Al-Nakib, W., Best, J. M., and Banatvala, J. E. (1974). Rubella-specific IgM and a new inhibitor. Br. med. J., 3, 579.

Best, J. M., Banatvala, J. E. and Watson, D. (1969). Serum IgM and IgG response in postnatally acquired rubella. Lancet, 2,65 .

Bürgin-WolfF, A., HernandeZ, R. AND JuST, M. (1971). Separation of rubella IgM, IgA and IgG antibodies by gel filtration on agarose. Lancet, $2,1278$.

Cradock-Watson, J. E., Bourne, M. S. and Vandervelde, E. M. (1972). IgG, IgA and IgM responses in acute rubella determined by the immunofluorescent technique. J. Hyg., Camb., 70, 473.

Francis, T. and MaASSAB, H. F. (1965). Influenza viruses. In Viral and rickettsial infection of man, 4th ed., edited by F. L. Horsfall and I. Tamm, Philadelphia, p. 689.

HoRWITZ, M. S. AND SCHARFF, M. D. (1969). In Immunological precipitation of radio-actively labeled viral proteins. Fundamental techniques in virology, edited by K. Habel, and N. P. Salzman, London, p. 297.

Ogra, P. L., Kerr-Grant, D., Umana, G., Dzierba, J. and Weintraub, D. (1971). Antibody response in serum and nasopharynx after naturally acquired and vaccine-induced infection with rubella virus. New Eng. J. Med., 285, 1333.

Plotkin, S. A. (1968). Rubella virus. In Diagnostic procedures for viral and rickettsial infection. 4th ed., edited by E. H. Lennette and N. J. Schmidt, New York, p. 364.

TERRY, G. M. (1977). Host induced modification of Newcastle disease virus virion polypeptides. Archs Virol., 53, 295. 